\title{
PERANAN EKOSISTEM HUTAN MANGROVE PADA IMUNITAS TERHADAP MALARIA: STUDI DI KECAMATAN LABUHAN MARINGGAI KABUPATEN LAMPUNG TIMUR
}

\section{(ROLE OF MANGROVE FOREST ECOSYSTEM IN IMMUNITY TO MALARIA: STUDY IN SUB-DISTRICT LABUHAN MARINGGAI DISTRICT EAST LAMPUNG)}

\author{
Agung Kartika Putra ${ }^{1)}$, Samsul Bakri ${ }^{2)}$, dan Betta Kurniawan ${ }^{3)}$ \\ ${ }^{1)}$ Mahasiswa Jurusan Kehutanan Fakultas Pertanian Universitas Lampung, \\ ${ }^{2)}$ Staf Pengajar Jurusan Kehutanan Fakultas Pertanian Universitas Lampung, \\ ${ }^{3)}$ Staf Pengajar Fakultas Kedokteran Universitas Lampung, \\ Jl. Sumatri Brojonegoro No 1 Bandarlampung. 35145 \\ Email : agungkartikaputra@ymail.com \\ Phone : 085664258268
}

\begin{abstract}
ABSTRAK
Salah satu fungsi ekologi hutan mangrove adalah sebagai habitat berbagai nyamuk termasuk nyamuk penyebab penyakit malaria (Anopheles $s p$.). Wabah penyakit malaria bisa meningkat akibat terdegradasinya hutan mangrove. Kondisi hutan mangrove yang buruk menstimulasi nyamuk Anopheles sp. untuk bermigrasi ke habitat lain seperti pemukiman, yang selanjutnya menjadi vektor penyakit malaria. Tujuan dari penelitian ini adalah untuk menentukan pengaruh ekosistem hutan mangrove baik faktor instrinsik maupun faktor ekstrinsik pada imunitas masyarakat terhadap malaria. Penelitian ini dilakukan pada bulan Juni 2014 di Desa Muara Gading Mas, Bandar Negeri, Sriminosari, dan Margasari, Kecamatan Labuhan Maringgai, Kabupaten Lampung Timur. Pengumpulan data dilakukan melalui wawancara dan metode survai/observasi lapang. Untuk mengetahui pengaruh setiap variabel digunakan model regresi logistik biner. Optimasi parameter menggunakan piranti lunak Minitab 16. Hasil penelitian menunjukan bahwa faktor yang dapat meningkatkan imunitas adalah: (a) jenis kelamin, laki-laki 37,42 kali perempuan, (b) umur, setiap bertambah tua 1 tahun berlipat menjadi 1,17 kali semula, (c) pendidikan, semakin tinggi maka berkurang menjadi 0,001 kali semula, (d) mata pencaharian, selain nelayan 0,001 kali nelayan, (e) jarak rumah terhadap fasilitas kesehatan, setiap berkurang 1 meter berlipat menjadi 0,09 kali semula, (f) jarak rumah terhadap mangrove, setiap bertambah 1 meter berlipat menjadi 1,001 kali semula, $(\mathrm{g})$ tempat sampah, ada tempat sampah 239,71 daripada tidak ada, (h) program malaria, berlipat 3,71E+05 kali semula daripada tidak ada, (i) luas mangrove, setiap bertambah $1 \mathrm{~m}^{2}$ menjadi 1,001 kali semula, dan (j) kerapatan vegetasi mangrove, setiap bertambah 1 populasi/ha berlipat 1,18 kali semula.
\end{abstract}

Kata kunci: Hutan mangrove, imunitas terhadap malaria, Anopheles sp.

\section{ABSTRACT}

One of the ecological function of mangrove forests is a habitat for mosquitoes that cause malaria (Anopheles sp.). Epidemic of malaria could increased as a result of mangrove degradation. The damage of mangrove forests stimulate Anopheles sp. migrate to other habitats such as settlements, that become malaria vector. The purpose of this research was to determine the effect of mangrove forest ecosystems both intrinsic and extrinsic factors in immunity to malaria. This research was conducted on June 2014 in the Muara Gading Mas Village, Bandar Negeri, Sriminosari, and Margasari, Sub-district Labuhan Maringgai, District East Lampung. The data were collected through interviews and survey/observations 
method. The impact of each variable used binary logistic regression models. Parameter optimization used software Minitab 16. The result of research have been demonstrated that there is influence both intrinsic and extrinsic factors in immunity to malaria in mangrove forest. Factors that increase resistance to malaria: (a) gender, male37.42 fold of female, $(b)$ age, getting older every 1 year doubled to 1.17 times of originally, (c) education, the higher it isreduced to 0.001 times the originally, (d) livelihood, besides fisher 0,001 fold of fisherman, (e) the distance settlements to the health facility, each reduced to 1 meter doubled to 0.09 times the originally, $(f)$ the distance home to mangroves, each increase of 1 meter doubled to 1,001 times the originally, $(g)$ the dustbin, there are bins 239.71 better than none, $(h)$ the malaria program, multiply 3,71E+05 originally than none, (i) extensive mangrove, increasing $1 \mathrm{~m}^{2}$ become 1,001 fold of originally, and $(j)$ mangrove density, increasing 1 population/ha multiply 1.18 fold originally.

Keywords: Mangrove forest, immunity to malaria, Anopheles sp.

\section{PENDAHULUAN}

\section{Latar Belakang}

Fungsi ekologi hutan mangrove merupakan satu dari dua fungsi lain ekosistem kawasan mangrove, yakni sebagai fungsi ekonomi dan fungsi sosial (Kustanti, 2011). Menurut Rahmawaty (2006), beberapa fungsi ekologi yang dimiliki hutan mangrove adalah sebagai tempat daerah asuhan, tempat mencari makan dan daerah pemijahan bagi berbagai biota laut, tempat bersarangnya burung, habitat alami bagi berbagai jenis biota, sumber plasma nutfah (hewan, tumbuhan dan mikroorganisme) dan pengontrol penyakit seperti malaria.

Malaria merupakan penyakit menular yang disebabkan oleh infeksi Protozoa dari genus Plasmodium yang berisiko kematian tinggi dengan proses penularan yang relatif cepat. Penyakit malaria hanya terjadi melalui perantara (vektor) nyamuk betina khususnya Anopheles sp. Terdapat sekitar 80 spesies Anopheles sp. di Indonesia, sedangkan yang dinyatakan sebagai vektor malaria adalah sebanyak 22 spesies dengan tempat perindukan yang berbeda-beda. Spesies nyamuk di Sumatera yang sudah dinyatakan sebagai vektor adalah Anopheles sundaicus, Anopheles maculatus, Anopheles nigerimus, Anopheles sinensis, dan Anopheles lettife (Ahmadi, 2008).

Hutan mangrove sebagai habitat nyamuk dapat mempengaruhi kehidupan larva nyamuk karena kanopi tegakan mangrove dapat menghalangi sinar matahari yang masuk atau melindungi dari serangan makhluk hidup lain, sehingga larva tersebut dapat berkembang biak dengan baik di dalam hutan mangrove tersebut (Ahmadi, 2008). Munculah asumsi bahwa dengan adanya hutan mangrove sebagai habitat nyamuk maka daerah jelajah nyamuk khususnya Anopheles sp. hanya di dalam dan sekitar hutan mangrove itu saja, sehingga kawasan penduduk akan aman dari serangan nyamuk tersebut pada radius jarak tertentu. Berbeda jika kualitas dan kuantitas hutan mangrove tersebut buruk, seperti terjadinya pembukaan areal hutan mangrove yang dapat menimbulkan masalah kesehatan. Kementerian Kesehatan RI (2011) telah membuktikan bahwa populasi nyamuk meningkat sebagai akibat ditebangnya hutan mangrove, sehingga dapat menimbulkan kerawanan terhadap wabah penyakit malaria.

Kesehatan masyarakat merupakan salah satu faktor pembangun kesejahteraan sosial yang sangat perlu diperhatikan, oleh karena itu pengaruh ekosistem hutan mangrove pada imunitas masyarakat terhadap malaria perlu diketahui khususnya angka kejadian pada masyarakat di sekitar hutan mangrovedi Kecamatan Labuhan Maringgai. Argumentasi tersebut merupakan simpul masalah yang perlu dipecahkan melalui penelitian ini. Pemecahan masalah ini menjadi semakin penting mengingat dinamika perubahan ekosistem 
hutan mangrove di daerah pesisir Lampung Timur begitu pesat dalam satu dasawarsa (Yuliasamaya dkk, 2014).

\section{Tujuan Penelitian}

Menentukan pengaruh ekosistem hutan mangrove baik faktor instrinsik maupun faktor ekstrinsik pada imunitas terhadap penyakit malaria.

\section{Kerangka Pemikiran}

Penelitian ini akan mengkaji peranan ekosistem hutan mangrove secara ekologi yaitu peranan ekosistem hutan mangrove terhadap kesehatan masyarakat yang ditinjau dari penyakit endemik di daerah pesisir yaitu penyakit malaria. Keterkaitan tersebut dapat dilihat dari beberapa faktor ekstrinsik seperti jenis kelamin, umur, tingkat pendidikan (SD, SMP, dan SMA), mata pencaharian, jarak rumah penduduk terhadap fasilitas kesehatan (Pustu, Puskesmas, Puskesdes, Puskeskec, dan lain-lain), tempat pembuangan sampah, dan program penyakit malaria. Faktor intrinsik yaitu jarak rumah penduduk terhadap hutan mangrove, luas hutan mangrove dan kerapatan asosiasi mangrove. Formula dibentuk dengan manggabungkan kedua faktor intrinsik dan ekstrinsik sebagai variabel independen serta variabel ketahanan terhadap penyakit malaria menjadi variabel dependen. Model akan diregresikan menggunakan Minitab16.

\section{METODE PENELITIAN}

\section{Tempat dan Waktu Penelitian}

Penelitian ini telah dilakukan di empat desa yaitu Desa Muara Gading Mas, Desa Bandar Negeri, Desa Sriminosari, dan Desa Margasari di Kecamatan Labuhan Maringgai, Kabupaten Lampung Timur. Pemilihan desa ditentukan karena di Desa Sriminosari dan Desa Margasari memiliki hutan mangrove dengan kondisi baik, sedangkan di Desa Muara Gading Mas serta Desa Bandar Negeri memiliki hutan mangrove dengan kondisi buruk. Waktu penelitian dilakukan pada bulan Juni 2014.

\section{Bahan dan Alat yang Digunakan}

Bahan-bahan yang digunakan dalam penelitian ini adalah data berupa citra satelit Landsat path 123 row 64 dengan perekaman peta luas kawasan hutan mangrove tahun 2013 serta masyarakat sebagai responden. Alat-alat yang digunakan meliputi alat tulis, alat ukur tinggi pohon (Christen Hypsometer), alat ukur diameter pohon (Pita Meter), GPS (Global Positioning System), laptop, kamera, ArcGIS 10, Minitab versi 16, Microsoft Office Word dan Microsoft Excel.

\section{Jenis Data}

Data primer yaitu luas kawasan hutan mangrove, kerapatan vegetasi hutan mangrove, dan hasil kuisioner berupa identitas responden dan prevalensi malaria (jumlah masyarakat yang terjangkit penyakit malaria). Data sekunder yang digunakan dalam penelitian ini adalah citra satelit Landsat path 123 row 64 lahan mangrove tahun 2013, kondisi umum lokasi penelitian dan sejarah hutan mangrove di lokasi tersebut.

\section{Metode Pengumpulan Data}

Metode yang digunakan adalah metode survai/observasi untuk mengumpulkan data primer. Data primer diperoleh dengan cara pengukuran langsung dan pembagian kuisioner kepada masyarakat. Data sekunder diperoleh dengan cara mengumpulkan data citra satelit, data mengenai kesehatan masyarakat secara umum dapat diperoleh dari adanya layanan 
kesehatan seperti Puskesmas Desa, Puskesmas Kecamatan, instansi-instansi terkait, serta studi pustaka.

\section{Metode Pengambilan Sampel}

Pengukuran kerapatan asosiasi mangrove dilakukan menggunakan metode plot garis berpetak dengan jumlah 5 petak contoh pada tiap kawasan hutan mangrove di masing-masing desa. Jumlah kepala keluarga dalam penelitian ini adalah $7.470 \mathrm{KK}$ dan sampel berjumlah 99 KK. Jumlah responden di Desa Margasari yaitu 25 KK, Sriminosari berjumlah 22 KK, Muara Gading Mas berjumlah 37 KK, dan Bandar Negeri berjumlah 15 KK.

\section{Analisis Data}

Analisis data dalam penelitian ini menggunakan persamaan regresi logistik biner (binary logistic regression) dengan persamaan $\{1\}$ yaitu:

$$
\begin{aligned}
{[\mathrm{Y}]_{\mathrm{i}}=} & \alpha_{0}+\alpha_{1}\left[\mathrm{D}_{1 \_} \mathrm{KLM}\right]_{\mathrm{i}}+\alpha_{2}[\mathrm{UMR}]_{\mathrm{i}}+\alpha_{3}\left[\mathrm{D}_{2 \_} \mathrm{SD}\right]_{\mathrm{i}}+\alpha_{4}\left[\mathrm{D}_{2} \mathrm{SMP}\right]_{\mathrm{i}} \\
& +\alpha_{5}\left[\mathrm{D}_{2} \mathrm{SMA}\right]_{\mathrm{i}}+\alpha_{6}\left[\mathrm{D}_{3 \_} \mathrm{PCHR}\right]_{i}+\alpha_{7}[\mathrm{JRK}-\mathrm{KES}]_{i}+\alpha_{8}[\mathrm{JRK}-\mathrm{M}]_{\mathrm{i}} \\
& +\alpha_{9}\left[\mathrm{D}_{4 \_} \mathrm{SMPH}\right]_{\mathrm{i}}+\alpha_{10}\left[\mathrm{D}_{5} \mathrm{PMLR}_{\mathrm{i}}+\alpha_{11}[\mathrm{LM}]_{\mathrm{i}}+\alpha_{12}[\mathrm{KM}]_{\mathrm{i}}+e\right.
\end{aligned}
$$

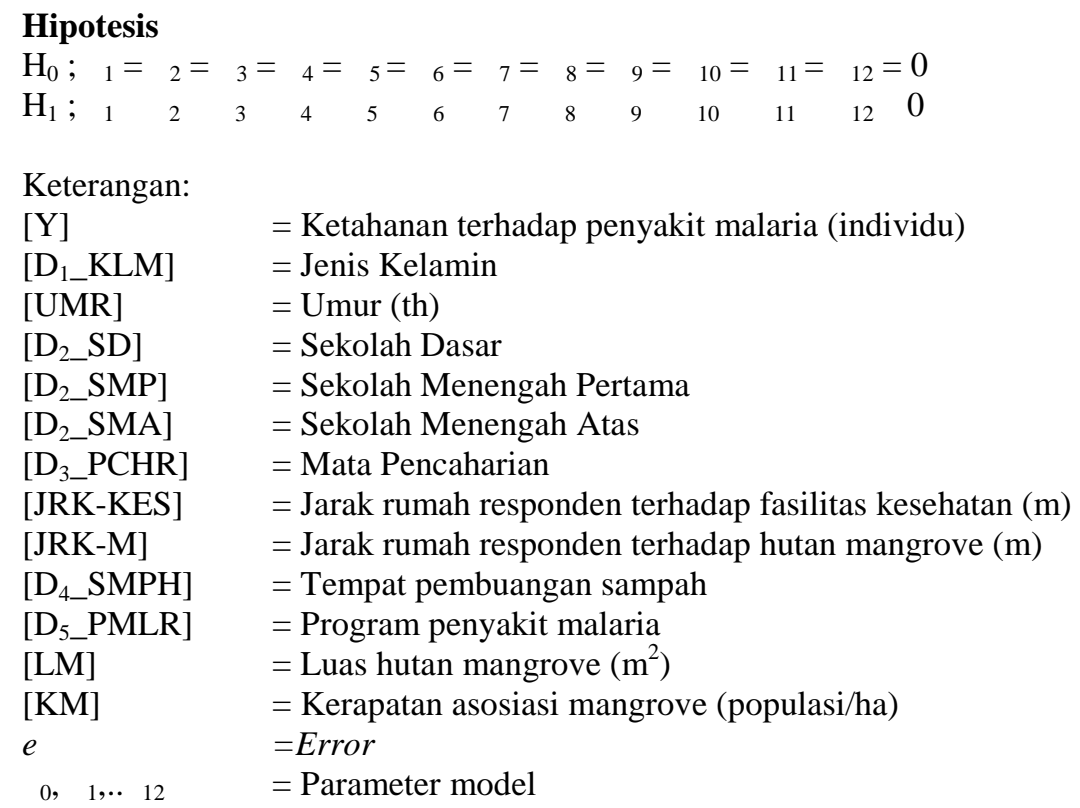

\section{Uji Hipotesis}

Uji parameter persamaan regresi logistik biner akan menggunakan piranti lunak Minitab versi 16. Signifikansi pengaruh variabel independen terhadap variabel dependen model tersebut akan digunakan uji $\mathrm{G}$, sedangkan uji masing-masing parameter terhadap variabel tetap akan digunakan uji $\mathrm{W}$ pada taraf nyata $1 \%, 5 \%$, dan $10 \%$.

\section{HASIL PEMBAHASAN}

Hasil optimasi parameter model dari penelitian ini disajikan pada Tabel 1. Atas dasar parameter model yang diperoleh maka secara matematik model peluang biner hasil penelitian ini diungkapkan pada masing-masing variabel independen terhadap variabel dependen. 
Tabel 1.Ringkasan hasil optimasi parameter model pengaruh ekosistem hutan mangrove pada imunitas masyarakat terhadap penyakit malaria.

\begin{tabular}{|c|c|c|c|c|c|c|}
\hline Predictor & Simbol & $\operatorname{Coef}\left(\alpha_{n}\right)$ & StDev & $\mathbf{Z}$ & $\mathbf{P}$ & Odds Ratio \\
\hline Constant & $\mathrm{Co}$ & 13 & 9.309 & 0,00 & 0,999 & - \\
\hline Jenis kelamin & $\mathrm{D}_{1 \_\mathrm{KLM}}$ & $\alpha_{1}=3,622$ & 1,309 & 2,77 & 0,006 & 37,42 \\
\hline Umur & UMR & $\alpha_{2}=0,15903$ & 0,06873 & 2,31 & 0,021 & 1,17 \\
\hline \multirow[t]{3}{*}{ Pendidikan } & $\mathrm{D}_{2} \_\mathrm{SD}$ & $\alpha_{3}=-20$ & 9.309 & $-0,00$ & 0,999 & 0,001 \\
\hline & $\mathrm{D}_{2} \_\mathrm{SMP}$ & $\alpha_{4}=-17$ & 9.309 & $-0,00$ & 0,999 & 0,001 \\
\hline & $\mathrm{D}_{2} \_\mathrm{SMA}$ & $\alpha_{5}=-9$ & 9.309 & $-0,00$ & 0,999 & 0,001 \\
\hline Mata Pencaharian & $\mathrm{D}_{3}$ PCHR & $\alpha_{6}=-6.220$ & 1,787 & $-3,48$ & 0,001 & 0,001 \\
\hline Jrk rumah-kes. & JRK-KES & $\alpha_{7}=-0,004306$ & 0,001169 & $-3,68$ & 0,0001 & 0,09 \\
\hline Jrk rumah- Mangrove & JRK-M & $\alpha_{8}=0,001770$ & 0,001025 & 1,73 & 0,084 & 1,001 \\
\hline Tempat sampah & $\mathrm{D}_{4 \_} \mathrm{SMPH}$ & $\alpha_{9}=5,479$ & 1,344 & 4,08 & 0,0001 & 239,71 \\
\hline Program malaria & $\mathrm{D}_{5 \_}$PMLR & $\alpha_{10}=12,824$ & 3,682 & 3,48 & 0,0001 & $3,71 \mathrm{E}+05$ \\
\hline Luas mangrove & LM & $\alpha_{11}=4,2604 \mathrm{E}+09$ & $3,198 \mathrm{E}+09$ & 1,33 & 0,183 & 1,001 \\
\hline Kerapatan mangrove & KM & $\alpha_{12}=0,0009500$ & 0,0003244 & 2,93 & 0,003 & 1,18 \\
\hline
\end{tabular}

Sumber : Hasil Penelitian (2014).

Berdasarkan hasil optimasi parameter dapat diketahui relasi faktor intrinsik hutan mangrove serta faktor ekstrinsik dapat dirumuskan dengan persamaan $\{2\}$ sebagai berikut:

$$
\begin{aligned}
\operatorname{Ln}\left\{\mathrm{P}(\mathrm{X}) /(1-\mathrm{P}(\mathrm{X})\}=\mathrm{Y}_{\mathrm{i}}=\right. & 13+3,622^{(* * *)}\left[\mathrm{D}_{1} \_\mathrm{KLM}\right]+0,115903^{(* *)}[\mathrm{UMR}]-20\left[\mathrm{D}_{2} \_\mathrm{SD}\right] \\
& -17\left[\mathrm{D}_{2} \_\mathrm{SMP}\right]-9\left[\mathrm{D}_{2} \_\mathrm{SMA}\right]-6,220^{(* * *)}\left[\mathrm{D}_{3} \mathrm{PCHR}\right] \\
& -0,004306^{(* * *)}[\mathrm{JRK} \text { KES }]+0,00177^{(*)}[\mathrm{JRK} \mathrm{MR}] \\
& +5,479^{(* * *)}\left[\mathrm{D}_{4} \mathrm{SMPH}\right]+12,824^{(* * *)}\left[\mathrm{D}_{5} \mathrm{PMLR}\right] \\
& +0,42604\left[10^{-8} \mathrm{LM}\right]+0,00095^{(* * *)}[\mathrm{KM}]
\end{aligned}
$$

$\mathrm{G}=176.253$ dengan $P_{\text {value }}=0.001$

Catatan: $(*)$ nyata pada taraf $10 \%,(* *)$ nyata pada taraf $5 \%$, dan $(* * *)$ sangat nyata pada taraf $1 \%$.

Hasil uji Gald sebesar 176.253 dengan $P_{\text {value }}=0,001$ (sangat nyata). Hasil uji Wald yaitu peran masing-masing variabel independen terhadap variabel respon (dependen) akan diuraikan sebagai berikut:

\section{Jenis kelamin}

Faktor jenis kelamin terhadap ketahanan penyakit malaria memiliki nilai $\alpha$ positif yaitu $\alpha_{1}=3,622$ sehingga dapat disimpulkan bahwa jika faktor lain tetap maka jenis kelamin lakilaki lebih besar terhindar dari serangan penyakit malaria 37,42 kali dibanding dengan jenis kelamin perempuan, pengaruh ini sangat nyata karena $P_{\text {value }}$ sebesar $0,60 \%$. Temuan ini menunjukkan bahwa jenis kelamin laki-laki memiliki ketahanan tubuh yang lebih baik dibandingkan jenis kelamin perempuan. Fenomena ini dapat difahami karena laki-laki cenderung memiliki aktifitas yang lebih besar dibandingkan perempuan sehingga membuat tubuh menjadi lebih bugar dan tahan terhadap penyakit. Keberadaan siklus tertentu pada perempuan seperti kehamilan (Rusmana, 2009) dan menstrusasi (Medicinus, 2013) akan mempengaruhi sistem imun. Saat perempuan mengalami siklus tersebut makan daya tahan tubuh akan menurun, sehingga akan berdampak pada kerentanan timbulnya penyakit khususnya malaria ketika nyamuk Anopheles sp menggigit. Pada penelitian ini jumlah responden yang berjenis kelamin laki-laki adalah 72 orang $(72,72 \%)$ dan perempuan berjumlah 27 orang $(27,27 \%)$.

\section{Umur}

Nilai $\alpha$ pada variabel umur yaitu $\alpha_{2}=0,15903$ (positif) sehingga pengaruhnya terhadap tingkat ketahanan penyakit malaria pada rentang usia 8-70 tahun (data responden 
penelitian) yaitu setiap umur bertambah 1 tahun maka peluang terhindar dari serangan penyakit malaria menjadi 1,17 kali semula, pengaruh usia ini nyata pada taraf $5 \%$ seperti dicerminkan oleh nilai $P_{\text {value }}$ sebesar $2,10 \%$. Penelitian lain yang telah dilakukan oleh Ernawati dkk (2011) juga membuktikan bahwa usia dewasa cenderung lebih tahan terhadap penyakit malaria daripada usia anak-anak dan bayi, hal tersebut berkaitan dengan tingkat variasi keterpaparan gigitan nyamuk. Intensitas keterpaparan yang tinggi pada usia anakanak akan membuat imunitas orang tersebut pada saat dewasa akan tinggi, karena sistem kekebalan tubuh akan terbentuk dan berkembang secara kompleks seiring terpaparnya manusia terhadap suatu penyakit yang diidap sebelumnya. Sistem imun berkembang sesuai dengan perkembangan tubuh kita. Menurut Kusumo (2012) pada waktu bayi umumya sistem imun masih belum banyak berkembang, beberapa komponen masih belum dapat bekerja optimal. Seiring bertambahnya usia dari anak-anak menuju remaja hingga dewasa, sistem imun berkembang untuk bekerja lebih optimal. Menurut Fatmah (2006) saat manusia memasuki usia tua sistem imun menurun kembali, oleh karena itu anak-anak dan lansia mudah sekali terkena penyakit.

\section{Pendidikan}

Hasil penelitian ini menggambarkan adanya trend yaitu semakin tinggi derajat pendidikan seseorang maka tingkat kepekaan terhadap serangan penyakit malaria semakin meningkat sebagaimana ditunjukkan oleh nilai-nilai parameter $\alpha_{3-5}$ yang bernilai negatif yaitu $\alpha_{3}=-20$ (SD), $\alpha_{4}=-17$ (SMP), dan $\alpha_{5}=-9$ (SMA). Trend terhadap penyakit malaria tersebut pengaruhnya tidak nyata sebagaimana ditunjukkan oleh $P_{\text {value }}$ masing-masing sebesar $99,90 \%$ dan Odds Ratio 0,001, artinya peluang untuk terkena penyakit malaria hanya sebesar 1/0,001 kali semula dari jenjang pendidikan dibawahnya. Menurut Suryandari (2013), masyarakat berpendidikan tinggi belum tentu terhindar dari serangan penyakit lebih baik dibandingkan dengan masyarakat berpendidikan lebih rendah.

Hasil penelitian ini menunjukkan jumlah responden yang tidak lulus SD adalah 6 orang, lulus SD berjumlah 20 orang, lulus SMP berjumlah 22 orang dan lulus SMA berjumlah 51 orang. Sebagian besar masyarakat di lokasi penelitian telah memenuhi program pemerintah wajib belajar 9 tahun.

\section{Mata Pencaharian}

Masyarakat di lokasi penelitian sebagian besar berprofesi sebagai nelayan karena didukung oleh letak geografis desa yang terletak di daerah pesisir. Masyarakat yang berprofesi sebagai nelayan lebih banyak beraktifitas di luar rumah pada malam hari hingga esok paginya, Menurut Ariati dkk (2008), waktu nyamuk untuk menggigit manusia di malam hari yaitu antara pukul $21.00-05.00$, sehingga faktor mata pencaharian terutama profesi sebagai nelayan akan mudah terkena serangan nyamuk dan mengakibatkan terkena penyakit endemis daerah pesisir yaitu malaria. Masyarakat yang berprofesi selain nelayan memiliki peluang terhindar dari penyakit malaria menjadi 0,001 kali semula daripada masyarakat yang berprofesi sebagai nelayan dan pengaruh ini sangat nyata karena $P_{\text {value }}$ sebesar $0,10 \%$ dengan nilai $\alpha_{6}=-6.220$ (negatif). Jumlah responden yang berprofesi sebagai nelayan sebanyak 44 orang (44,44\%). Sebagian besar masyarakat di Desa Margasari dan Muara Gading Mas $(53,23 \%)$ adalah nelayan, sedangkan masyarakat di Desa Sriminosari dan Bandar Negeri berprofesi sebagai petani. Sehingga masyarakat di Margasari dan Muara Gading Mas cenderung lebih rentan terhadap penyakit malaria dibandingkan masyarakat di Desa Sriminosari dan Bandar Negeri.

Menurut Shinta dkk (2013), rata-rata kepadatan nyamuk hinggap pada manusia di dalam rumah lebih rendah daripada di luar rumah. Manusia yang mempunyai aktivitas di luar rumah pada malam hari akan mempunyai risiko lebih besar terjadi kontak langsung 
dengan nyamuk vektor penyebab penyakit malaria. Hasil penelitian yang serupa juga telah dilakukan oleh Ernawati dkk (2011), menunjukkan bahwa kejadian infeksi malaria pada kelompok nelayan yang menginap mempunyai proporsi kejadian infeksi malaria lebih tinggi $(12,40 \%)$ dibandingkan dengan kelompok yang bekerja sebagai nelayan yang tidak menginap $(7,90 \%)$. Faktor lain seperti fisik juga mempengaruhi tingkat kesehatan manusia. Profesi sebagai nelayan cenderung mengeluarkan energi yang besar sehingga menyebabkan terjadinya penurunan daya tahan tubuh karena kelelahan, oleh karena itu bisa menimbulkan gangguan fungsi imun pada manusia (Agung, 2010).

\section{Jarak Rumah terhadap Fasilitas Kesehatan}

Faktor jarak rumah terhadap fasilitas kesehatan memiliki nilai $\alpha$ negatif $\left(\alpha_{7}=\right.$ 0,004306). $\alpha$ negatif bermakna jika semakin jauh jarak rumah terhadap fasilitas kesehatan di desa setempat maka peluang tidak sehat akan semakin besar. Setiap berkurangnya satu meter jarak antara rumah terhadap fasilitas kesehatan maka peluang sehat (tidak terkena penyakit malaria) menjadi 0,09 kali semula, pengaruhnya sangat nyata karena $P_{\text {value }}$ sebesar $0,01 \%$. Kondisi aksesbilitas jarak rumah terhadap fasilitas kesehatan di masing-masing desa cukup terjangkau, sehingga mayarakat cenderung berobat ke Puskesmas, Puskesdes, Pustu, dll.

Menurut Saikhu (2011),semakin jauh jarak rumah terhadap fasilitas kesehatan maka angka kejadian malaria akan meningkat, hal tersebut menyangkut masalah keterjangkauan akses masyarakat. Hasil ini juga sejalan dengan hasil penelitian yang telah dilakukan oleh Sari dkk (2013), bahwa ada hubungan yang bermakna antara jarak dengan perilaku pencarian pengobatan malaria klinis. Penundaan waktu untuk memperoleh pengobatan yang tepat dapat mengakibatkan bertambahnya jumlah penderita baru karena penderita malaria (lama) dapat menjadi sumber penularan.

\section{Jarak Rumah terhadap Hutan Mangrove}

Faktor jarak rumah terhadap hutan mangrove memiliki nilai $\alpha$ positif $\left(\alpha_{8}=0,001770\right)$. Nilai $\alpha$ positif mencerminkan bahwa semakin jauh jarak rumah terhadap hutan mangrove maka jumlah masyarakat yang terjangkit penyakit malaria akan semakin berkurang. Jika jarak rumah bertambah satu meter lebih jauh dari hutan mangrove maka peluang sehat atau tidak terkena penyakit malaria menjadi 1,001 kali semula. Variabel ini berpengaruh nyata pada taraf $10 \%$ karena $P_{\text {value }}$ sebesar $8,40 \%$. Jarak rumah terhadap hutan mangrove berkisar antara $0-3000 \mathrm{~m}$, dengan modus $2000 \mathrm{~m}$.

Jarak terbang nyamuk merupakan faktor yang sangat berpengaruh dalam upaya nyamuk vektor malaria mencari tempat untuk istirahat, tempat untuk mencari makanan, dan tempat untuk berkembang biak (Sushanti, 1999). Risiko penularan malaria tergantung pada jarak terbang nyamuk Anopheles sp. yang terbatas, biasanya tidak lebih dari $2 \mathrm{~km}$ dari tempat perindukannya (Departemen Kesehatan RI, 1999) yang dalam penelitian ini adalah hutan mangrove. Peran hutan mangrove sebagai habitat nyamuk (Masela, 2012), menyebabkan nyamuk tersebut cenderung tidak akan keluar dari hutan mangrove, utamanya pada hutan mangrove yang belum terganggu.

\section{Tempat Pembuangan Sampah/Limbah}

Peran adanya tempat pembuangan sampah atau limbah pada masing-masing rumah tangga mempunyai nilai positif $\left(\alpha_{9}=5,479\right)$ terhadap ketahanan penyakit malaira. Semakin banyak masing-masing rumah tangga yang memiliki tempat pembuangan sampah/limbah sendiri, maka jumlah masyarakat yang terjangkit penyakit malaria semakin rendah menjadi 239,71 kali semula daripada yang tidak memiliki tempat pembuangan sampah/limbah dan pengaruhnya sangat nyata $\left(P_{\text {value }}=0,01 \%\right)$. Hasil penelitian ini didukung oleh penelitian yang telah dilakukan oleh Saikhu (2011), bahwa ada hubungan bermakna nyata antara 
masyarakat yang memiliki tempat pembuangan sampah/limbah terhadap jumlah pengidap penyakit malaria. Sanitasi yang baik mampu mengeradikasi (memusnahkan) habitat nyamuk Anopheles sp. yang sudah keluar dari habitat yaitu mangrove menuju perkampungan. Eradikasi tersebut meliputi hilangnya tempat-tempat lembab ataupun tampungan-tampungan air hujan yang disebabkan oleh adanya tumpukan-tumpukan sampah yang tidak terkelola secara baik. Responden yang sudah memiliki tempat pembuangan sampah sendiri yaitu sebanyak 72 orang $(72,72 \%)$, sehingga dapat menggambarkan masyarakat di lokasi penelitian secara keseluruhan telah faham akan pentingnya kaitan keberadaan tempat pembuangan sampah dengan kesehatan khususnya malaria.

\section{Program Malaria}

Responden yang pernah mengikuti program pemberantasan penyakit malaria dapat dilihat dari nilai $\alpha_{10}=12,824$ (positif) yang menggambarkan bahwa ada keterkaitan antara variabel tersebut terhadap ketahanan penyakit malaria yang terjadi di masyarakat. Responden yang pernah mengikuti program malaria cenderung lebih sehat menjadi 3,71E+05 kali semula daripada responden yang tidak pernah mengikuti program tersebut dan pengaruhnya sangat nyata karena $P_{\text {value }}$ bernilai $0,001 \%$. Kejadian infeksi malaria berdasarkan pengetahuan, menunjukkan bahwa semakin rendah tingkat pengetahuan seseorang mengenai penyakit malaria, maka semakin besar risiko untuk terinfeksi penyakit endemis pesisir tersebut. Program dinas kesehatan setempat pernah melakukan penyuluhan mengenai tata cara pemberantasan penyakit malaria serta melakukan kegiatan pengasapan, namun program tersebut hanya dilakukan di Desa Sriminosari saja. Kegiatan-kegiatan yang secara signifikan mampu mencegah penyakit malaria yaitu memakai obat nyamuk saat tidur, memakai kelambu, mempersempit adanya lubang pada bagian dinding rumah seperti ventilasi udara, kegiatan pengasapan, keberadan genangan air, ketersediaan tempat pembuangan sampah/limbah serta saluran sanitasi, dan mengurangi aktivitas di luar rumah pada malam hari (Priyandina, 2011).

\section{Luas Hutan Mangrove}

Peran variabel luas hutan mangrove memiliki dampak positif $\left(\alpha_{11}=4,2604 \mathrm{E}+09\right)$, dengan demikian dapat dijelaskan bahwa semakin bertambah luas hutan mangrove setiap meter persegi maka jumlah penyakit malaria akan menurun menjadi 1,001 kali semula, tetapi pengaruh ini tidak nyata karena $P_{\text {value }}$ sebesar $18,30 \%\left(P_{\text {value }} \geq 10 \%\right)$. Hasil penelitian ini menunjukkan bahwa hutan mangrove sebagai habitat nyamuk penyebab penyakit malaria berpengaruh kecil terhadap peredaman penyakit malaria yang terjadi di masyarakat. Munculah indikasi walaupun jumlah luasan hutan mangrove yang besar namun densitas asosiasi pembentuk hutan mangrove belum tentu besar pula. Pengaruh ini ditunjang juga oleh adanya tegakan tanaman mangrove masih berupa semai dengan kerapatan 25.000 (populasi/ha) dan pancang 4.000 (populasi/ha) sehingga belum berperan sebagai tempat yang favorable bagi siklus kehidupan nyamuk pembawa penyakit malaria tersebut. Luas hutan mangrove di Desa Muara Gading Mas adalah 0 ha (dengan pembulatan karena tidak mencapai 1 ha), di Desa Bandar Negeri adalah 5,8 ha, di Desa Sriminosari adalah 321,81 ha, dan di Desa Margasari adalah 817,59 ha. Telah terjadi peningkatan luas hutan mangrove di Desa Margasari yaitu 700 ha pada tahun 2005 (Lemlit Unila 2011) dan pada tahun 2014 sudah mencapai 817,59 ha sesuai dengan hasil penelitian ini. Desa Margasari dan Sriminosari yang memiliki luas hutan mangrove yang tinggi mampu menekan prevalensi penyakit malaria. Prevalensi penyakit malaria yang terjadi di kedua tersebut sebesar 9,00\%, sedangkan di Desa Bandar Negeri dan Desa Muara Gading Mas yang memiliki luas hutan mangrove yang kecil memiliki angka kejadian malaria mencapai 18,18\%. 


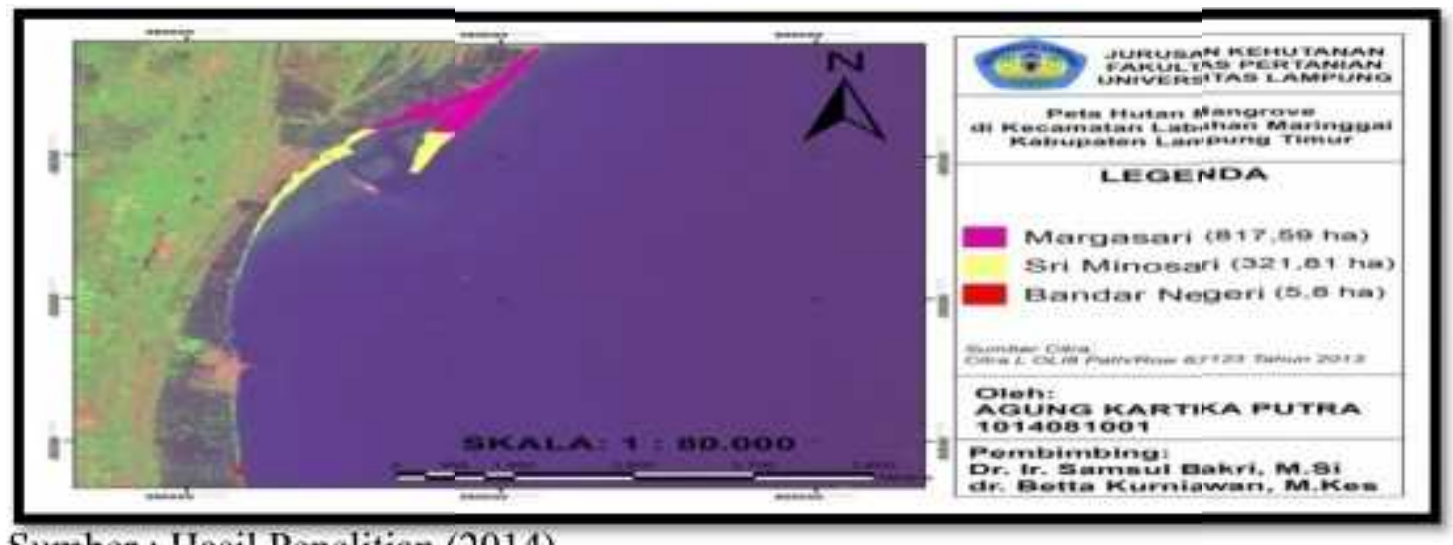

Sumber : Hasil Penelitian (2014).

\section{Kerapatan Asosiasi Mangrove}

Faktor kerapatan asosiasi vegetasi pembentuk hutan mangrove berpengaruh positif $\left(\alpha_{12}\right.$ $=0,0009500$ ) terhadap penurunan jumlah angka kejadian (prevalensi) penyakit malaria. Hasil dari regresi (Tabel 1) mencerminkan bahwa semakin tinggi tingkat kerapatan asosasi hutan mangrove maka jumlah penyakit malaria akan menurun menjadi 1,18 kali semula. Variabel kerapatan asosiasi hutan mangrove berpengaruh sangat nyata karena $P_{\text {value }}$ sebesar 0,03\%. Hasil ini ditunjang oleh penelitian yang telah dilakukan oleh Masela (2012) yang menyatakan bahwa, ada hubungan antara struktur dan komposisi tanaman mangrove terhadap kerapatan nyamuk. Jenis nyamuk yang ditemukan di hutan mangrove dalam penelitian yang telah dilakukan oleh Masela (2012) adalah Aedes sp., Culex sp., dan Anopheles sp. Kondisi tingkat kerapatan vegetasi mangrove di Desa Muara Gading Mas adalah 0 populasi/ha, di Desa Bandar Negeri adalah 7.960 populasi/ha, di Desa Sriminosari adalah 13.480 populasi/ha, dan di Desa Margasari adalah 10.440 populasi/ha. Densitas hutan mangrove di Desa Muara Gading Mas sangat jarang terutama untuk fase pohon serta luasan hutan mangrove yang tidak mencapai 1 ha sehingga dianggap memiliki nilai kerapatan 0 populasi/ha. Variabel ini telah membuktikan bahwa Desa Margasari dan Sriminosari yang memiliki densitas vegetasi mangrove tinggi mampu mengurangi prevalensi penyakit malaria yang terjadi di masyarakat dibandingkan kedua desa lainnya yaitu Desa Bandar Negeri dan Desa Muara Gading Mas yang memiliki kerapatan vegetasi mangrove rendah.

\section{KESIMPULAN}

Penelitian ini telah membuktikan bahwa ada pengaruh ekosistem hutan mangrove baik faktor intrinsik maupun faktor ekstrinsik pada imunitas masyarakat terhadap penyakit malaria. Faktor-faktor yang meningkatkan imunitas adalah: (a) jenis kelamin, laki-laki 37,42 kali perempuan, (b) umur, setiap bertambah tua 1 tahun berlipat menjadi 1,17 kali semula, (c) pendidikan, semakin tinggi maka berkurang menjadi 0,001 kali semula, (d) mata pencaharian, selain nelayan 0,001 kali nelayan, (e) jarak rumah terhadap fasilitas kesehatan, setiap berkurang 1 meter berlipat menjadi 0,09 kali semula, (f) jarak rumah terhadap mangrove, setiap bertambah 1 meter berlipat menjadi 1,001 kali semula, (g) tempat sampah, ada tempat sampah 239,71 daripada tidak ada, (h) program malaria, berlipat 3,71E+05 kali semula daripada tidak ada, (i) luas mangrove, setiap bertambah $1 \mathrm{~m}^{2}$ menjadi 1,001 kali semula, dan (j) kerapatan vegetasi mangrove, setiap bertambah 1 populasi/ha berlipat 1,18 kali semula. 


\section{DAFTAR PUSTAKA}

Agung, I. G. A. A. 2010. Pengaruh perbaikan gizi kesehatan terhadap produktivitas kerja. Skripsi. Fakultas MIPA Universitas Hindu Indonesia.Denpasar. 1-15p.

Ahmadi, Supri. 2008. Faktor risiko kejadian malaria di Desa Lubuk Nipis Kecamatan Tanjung Agung Kabupaten Muara Enim. Tesis. Program Studi Magister Kesehatan Lingkungan Universitas Diponegoro. Semarang. 12p.

Ariati, Y., Wigati, H. Andris, dan Sukowati. 2008. Bioekologi vektor nyamuk malaria Anopheles sundaicus di Kecamatan Nongsa, Kota Batam tahun 2008. Jakarta. 29$37 \mathrm{p}$.

Departemen Kesehatan RI. 1999. Pedoman Epidemiologi Penyakit Malaria. Buku. Dirjen PPM dan PLP. Jakarta. 15p.

Ernawati, K, S. Budhi, D. Artha, dan Rifqatussa'adah. 2011. Hubungan faktor risiko individu dan lingkungan rumah dengan malaria di Punduh Pedada Kabupaten Pesawaran Provinsi Lampung Indonesia 2010. Jurnal Makara, Kesehatan. 15(2): 51-55p.

Fatmah. 2006. Respon imunitas yang rendah pada tubuh manusia usia lanjut. Jurnal Makara. 10(1): 47-53p.

Kementerian Kesehatan RI. 2011. Epidemologi Malaria di Indonesia. Buku. Jakarta. 1-16p.

Kustanti, A, 2011. Manajemen Hutan Mangrove. Buku. Institut Pertanian Bogor Press. Bogor. 34p.

Kusumo, P. D. 2012. Kolonisasi mikrobiota normal dan pengaruhnya pada perkembangan sistem imunitas neotanal.Jurnal Widya. 29 (320): 55-63p.

Lembaga Penelitian Unila dan Balai Pengelolaan Hutan Mangrove Wilayah II. 2011. Ekowisata Mangrove Pesisir Lampung Timur. Buku. Lembaga Penelitian Unila. Bandar Lampung. 22p.

Masela, D. F. 2012. Pengaruh struktur dan komposisi mangrove bagi kerapatan nyamuk di Desa Kopi dan Desa Minanga Kecamatan Bintauna. Jurnal Cocos.1(2): 1-8p.

Medicinus. 2013. Dysmenorrhea dan endometriosis. Jurnal Medicinus: Scientific Journal of Pharmaceutical Development and Medical Application. 26(2): 1-67.

Priyandina, A. N. 2011. Pengaruh lingkungan dan perilaku terhadap kejadian malaria di Wilayah Kerja Puskesmas Sanggau Kecamatan Kapuas Kabupaten Sanggau.Jurnal Mahasiswa Pspd FK Universitas Tanjungpura. 1(1): 1-16p.

Rahmawaty. 2006. Upaya pelestarian mangrove berdasarkan pendekatan masyarakat. Skripsi. Fakultas Pertanian Universitas Sumatera Utara. Medan. 5p.

Rusmana, D. 2009. Aspek onkologi human papillomavirus. Jurnal Maranatha. 9(1): 95$101 \mathrm{p}$.

Saikhu, A. 2011. Faktor risiko lingkungan dan perilaku yang mempengaruhi kejadian kesakitan malaria di Propinsi Sumatera Selatan (analisis lanjut data riset kesehatan dasar 2007). Jurnal Penelitian Penyakit Tular Vektor Aspirator. 3(1): $1-10 \mathrm{p}$.

Sari. R. M., L. P. Ambarita, dan H. Sitorus. 2013. Akses pelayanan kesehatan dan kejadian malaria di Provinsi Bengkulu. Jurnal Penelitian dan Pengembangan Kesehatan. 23(4): $158-164 p$.

Shinta, S. Sukowati, A. Pradana, Marjianto, dan Putu Marjana. 2013. Beberapa aspek perilaku Anopheles maculatus theobald di Pituruh, Kabupaten Purworejo, Jawa Tengah. Jurnal Penelitian Kesehatan. 41(3): 131-141p.

Suryandari, D. 2013. Hubungan antara faktor jarak pelayanan dengan pemanfaatan pos kesehatan desa di Desa Gawanan Kecamatan Kolomadu. Skripsi. Universitas Muhammadiyah Surakarta. Surakarta. 164p. 
Sushanti, N. 1999. Fauna Anopheles di Daerah Bekas Pantai Mangrove Kecamatan Padang Cermin Kabupaten Lampung Selatan. Buletin Penelitian Kesehatan. 26(1): 1$14 \mathrm{p}$.

Yuliasamaya., A. Darmawan., dan R. Hilmanto. 2014. Perubahan tutupan hutan mangrove di Pesisir Kabupaten Lampung Timur (mangrove forest cover change along the coast of East Lampung Regency. Jurnal Sylva Lestari. 2(3): 111-124p. 
Vol. 3 No. 2, Mei 2015 (67-78)

Halaman ini sengaja dikosongkan 